\title{
Cultural Consensus About Happiness Among the Elderly
}

\author{
María de los Ángeles Aguilera-Velasco, PhD \\ Martín Acosta-Fernández, PhD \\ Sergio Adalberto Franco-Chávez, PhD \\ Rubén Soltero-Avelar, PhD \\ Universidad de Guadalajara, México
}

doi: 10.19044/esj.2017.v13n20p55 URL:http://dx.doi.org/10.19044/esj.2017.v13n20p55

\begin{abstract}
The purpose of this study was to analyze cultural consensus about happiness among the elderly by identifying meanings and conceptual dimensions of the concept. A qualitative study was made with an exploratory descriptive design in two successive phases, with free list and pile sorting by a non-random purposive sampling of 76 elderly adults with an average age of 65.35. The results evidenced cultural consensus in the two conceptual models of happiness, one for men and another for women, with high concordance in individual and group answers. The models consisted of two conceptual dimensions of happiness: economic stability and support. The models show limited happiness due to constant concerns of having employment and money to eat, live and buy medicine, which they can overcome thanks to the family support net. Specifically, men were more concerned about economic support for household expenses and for helping their siblings. On the other hand, women had a vision more focused on themselves and on their religious beliefs. The cultural meaning of happiness for women included children and tranquility while for men it meant health, children, wellbeing and family. The conclusion is that the elderly we studied are aware of the importance of their happiness and how to reach it. The looming limiting factor was being excluded from Social Security benefits and not having money or government support. We recommend the State lend support to these people with medical care and free medicine, offer sufficient stable economic support after their $60^{\text {th }}$ birthday, and promote knowledge and experiences to women beyond religious beliefs as well as the practices of laughter and peace among men for the purpose of widening their expectations by traveling, enjoying themselves and with leisure and recreational activities.
\end{abstract}


Keywords: Cultural consensus, Happiness, Elderly

\section{Introduction}

Mexico is a country where poverty and indigence are growing (Comisión Económica para Latina América y el Caribe [CEPAL], 2015). Vulnerability is also on the rise. Only $20.5 \%$ of the population is neither poor nor vulnerable. The other $79.5 \%$ live in poverty (36.7\%), in extreme poverty $(9.5 \%)$ or with the possibility of falling into poverty, whether due to social deficiencies (26.3\%) or to income (7\%). More than half the total poor are older than 65 years old. Eight-point five percent of the elderly live in extreme poverty (Consejo Nacional de Evaluación de la Política de Desarrollo Social [CONEVAL], 2015). Unfortunately, there is no evidence that poverty will decrease in the future.

Mexicans living in a state of poverty are characterized by having income below the poverty line and by social deficiencies, be it educational deficit, no access to health services, Social Security benefits or nourishment or basic housing services, or a lack of housing space and quality. The population in extreme poverty, besides having income below the minimum threshold of wellbeing, has three or more social deficiencies. The latest CONEVAL (2015) report showed that the most affected dimensions are access to Social Security benefits and the income level.

Notwithstanding the above, this country is listed among the 15 happiest countries in the world happiness reports between 2012 and 2015 (Helliwell, Layard \& Sachs, 2012; Helliwell et al., 2013; Helliwell et al., 2015). It dropped from $14^{\text {th }}$ place to $21^{\text {st }}$ in the 2016 report out of a total of 156 countries. This drop is due to an increase in inequality and the lack of sustainable national development goals (Helliwell et al., 2016). Even so, $21^{\text {st }}$ place out of 156 countries is high. The high levels of happiness in Mexico, comparable to that of developed countries, present a remarkable incongruence when compared to the country's high poverty rate.

Happiness was defined in the four world reports as a reflection of a country's development and the best indicator of a population's wellbeing, more so than measurements of income, poverty, education, health and good government when they are measured separately. Nevertheless, happiness was evaluated from people's individual perception and weighted with the Gross Domestic Product (GDP), life expectancy, social support and corruption. The authors of the reports estimate the possibility of happiness increasing in countries if helping others becomes an everyday practice, as occurs during natural disasters when people from around the world unite to help. On the other hand, they also mentioned that happiness may decrease if the social fabric is weak, or if there are economic crisis, natural disasters or 
war. They mentioned that in the State of Jalisco, Mexico, programs are being implemented for inhabitants to live happier but this has not been reflected in improvements of the country’s happiness (Helliwell et al., 2016).

On the other hand, by applying the theoretical economic model of the determining factors of happiness in the country, designed based on data from the National Household Expense Survey (ENGASTO) applied by the National Statistics and Geography Institute (INEGI), it was found that the Mexican population in general believes that happiness is mainly determined by its perception of its state of health (Salazar \& Arenas, 2016). Nevertheless, the model is not broad enough to explain the perception of happiness from a cultural point of view.

Happiness has been defined from numerous different viewpoints, philosophical (Mauri, 2015) as well as theoretical (Bueno, 2005), religious (Mauri, 2005) and geographical. For instance, happiness for Oriental countries is usually internal harmony. On the other hand, in Western countries it is aimed more at consumerism and the pursuit and permanence of beauty (Ramírez, 2017). The study of happiness goes back to before Christ, by important philosophers such as Tales de Mileto and Aristoteles, just to mention a couple. In the years following Christ, the most outstanding great thinkers that left us their concept of happiness include Descartes, Spinoza, Kierkegaard, Nietzsche, Freud, Jung and Sartre among others. Art, literature and politicians have also expressed their opinions about happiness, from Cervantes to Gandhi, Ann Frank and Vargas Llosa (SMU, 2013).

In the political arena, a study of happiness was initiated by the government of Bhutan, a country with a Buddhist government that was the first to gauge progress and quality of life by the happiness of its people with the so-named Gross National Happiness Index. It incorporated the pursuit of happiness into the political agenda and amended its constitution to guarantee free access to basic public health services (Sithey, Thow, \& Li, 2006). Countries such as Japan, Korea and Brazil have followed suit. Later the United Nations Organization (UN) incorporated the concept of happy country as a new economic paradigm that includes social and environmental progress to the efforts of attaining sustainable development (ONU, 2012). The study of happiness during the worldwide crisis of 2008-2009 gained strength in the political environment with the desire to help the poor and vulnerable sectors of society (Miret et al., 2014). Unfortunately, some authors such as Alvarado (2016) have criticized the right to happiness as one of the human rights because he maintains it is impossible for the State to make anyone happy.

Happiness has been researched in different scientific disciplines. One may say that philosophy studies its concept and reality; psychology 
determines individual and genetic factors; and sociology analyzes the social components of happiness (Barragán, 2013). Nonetheless, despite abundant literature about happiness, there is an underlying epistemic problem given the variety of the conceptual definitions and different models attempting to produce a unidimensional definition of happiness by trying to reduce multifactorial social convergence to individual perception.

For instance: the scientific approach to happiness has favored studies with unipersonal models whose outstanding contributions lie in considering that happiness and subjective wellbeing are equivalents (Escalante, 2016); that conservation values, openness to change and self-transcendence are the main factors favoring happiness in immigrants and young people (Bilbao, Techio, \& Paez, 2007); that social support networks such as God, oneself, a friend, mother or siblings, foster wellbeing (González-Quiñones \& RestrepoChavarriaga, 2010); that happiness is associated with food (Lobos, Mora, Lapo, Caligaria, \& Schnettler, 2015; Pinzón, 2017; Schnettler et al., 2014) and with health (Miret et al., 2014; Salazar \& Arenas, 206); and that the elderly have ambivalent definitions of old age as happiness, family bonds and life experiences but also as sickness, solitude and sadness (Pereira et al., 2014), Furthermore, there are validated scales for beliefs of happiness (Álvarez, 2012) and to measure happiness of the elderly (Árraga \& Sanchez, 2012). A multidimensional study of happiness was proposed recently with emphasis on affective relationships, prosocial behavior and investment in others (Carrillo, Feijoo, Gutiérrez, Jara, \& Schellekens, 2017). Notwithstanding the scope of these studies, they still have not been able to identify the cultural foundation of shared knowledge about happiness, thus actions by the persons involved cannot be explained. The foregoing puts us in a position of needing to know the sociocultural processes implied in the construction of the concept of happiness and the social interpretation thereof, expressed individually but that is constructed and reconstructed in socialindividual intercommunication.

Cultural studies would be a useful way to access understanding of the universe of people through their conceptions, meanings, values, language, knowledge and practices. In this regard, cultural conceptions about happiness pose a challenge to scientific research but there are deep roots in applying the term to different behaviors and the multiple considerations expressing its multicultural character (Helliwell et al., 2016). As a result, the difficulties in promoting it are diversified when considering the isolated data of people's cultural specificity. In this regard, an approach that can contribute a social viewpoint is the cultural consensus theory (Romney, Weller, \& Batchelder, 1986; Weller and Romney, 1988) that states that cultural knowledge within a specific context helps us define and guide the behavior of individuals, based 
on how the social subject understands everyday events, how he/she constructs shared knowledge and how it is deemed to be common sense.

Cultural consensus theory is a collection of analytical techniques and models that may be used to estimate cultural beliefs and the extent to which subjects know or report such beliefs. It estimates culturally appropriate or correct answers to questions and individual differences of cultural knowledge; i.e., it describes assumptions, proper interview material and analytical processes for extracting an analysis of the consensus (Romney, Boyd, Moore, Batchelder, \& Brazill, 1966). It grew out of a series of cultural theories describing the nature of some general phenomena (D'Andrade, 2003) and from the integration of several studies analyzing systemic cultural patterns (Kroeber in 1948, Roberts in 1951, D’Andrade in 1989, Romney, Weller and Batchelder in 1986, Romney and Moore in 1999, and Weller in 2007). The purpose is to be able to define and interpret semantic domains, provide a way to classify the elements of a cultural pattern and to integrate high concordance codes and formulate an analysis of the consensus. This closely follows the reasoning behind reliability theory, except that the analysis is made by the informants instead of articles (Chick, 2000).

With cultural consensus theory, qualitative data are extrapolated to a mathematical interpretation model and a situation is assumed where an ethnographer is not aware of how much each informant knows about the cultural domain under consideration or the answers to the questions. This proposed formal model includes true-false and multiple-choice questions as well as filling in spaces in familiar (known) cultural domains with very good results with as few as four informants (Borgatti, 1998; Chick, 2000; Weller, 2007). Consensus methods are not appropriate for group interviews. It includes just one topic and the same level of difficulty (homogeneity) for all informants. Consensus analysis does not create consensus; it only estimates the level of agreement present (Weller, 2007).

Nevertheless, despite the great benefits it may offer, studies about happiness with a cultural sense are scarce, the most noteworthy being research that found the conception of happiness subordinate to alcohol consumption (Castillo \& Costa, 2008). Cultural consensus models and cultural domains (that incorporate other models into the cultural consensus theory) have been developed in the area of health to describe knowledge of a social group about a specific disease. For example, patients' concerns about inoperable lung cancer were explored in Switzerland (Broberger, Tishelman, von Essen, Doukkali, \& Spangers, 2007); the social and psychological construction of healing was analyzed in the United States (Meza \& Fahoome, 2008); the primary health care work environment was explored in physicians (Walker, Clarke, Ryan, \& Brown, 2011); definitions of dignity were 
discovered in war veterans with spinal cord injuries (Lind, Powell-Cope, Chávez, Fraser \& Harrow, 2013); key dimensions of quality of life were identified in people with asthma (Ederhart et al., 2014); and the viewpoints of women with HIV were learned (Morrison, Sudha, Herrera, Ruiz, \& Thomas, 2016). And cultural dimensions of dengue were analyzed in health providers in Mexico and Colombia (Torres-López, Soltero-Avelar, \& Herrera-Pérez, 2012).

Cultural models have also been used recently in political studies; for instance, men and women in Kenya analyzed the relationships between gender, power and equity (Bourey, Stephenson, Bartel, \& Rubardt, 2012). These kinds of studies have also been used to recover cultural knowledge such as in indigenous communities in Pakistan where traditional knowledge was documented (Ahmad \& Pieroni, 2016); in the Bolivian Andes where the cultural importance of specific agroforest species for a peasant community was calculated (Brandt, Mathez-Stiefel, Lachmuth, Hensen, \& Rist (2013); a new classification of birds was found in Oaxaca, México (Alcántara-Salinas, Ellen, Valiñas-Coalla, Caballero, \& Argueta-Villamar, 2013), and the cultural domain of edible plants was characterized in Costa Rica (D’Ambrosio \& Puri, 2016).

A cultural consensus focus would be useful for approaching the domain of happiness; it would contribute a new dimension to the study by offering cultural models of happiness including cultural meanings and cognitive structures. According to Borgatti (1994), these kinds of models allow us to recognize whether shared knowledge exists within a social group with regards to a cultural domain, in this case happiness, and also allows us to recognize its structure and organization. Cultural domain consists of an organized set of words (lexemes or terms), concepts and sentences that as a unit refer to one conceptual sphere (Weller \& Romney, 1988).

In light of the above, the objective of this study was to analyze the cultural consensus of happiness in elderly adults by identifying meanings and conceptual dimensions of the concept for the purpose of creating new data enabling the creation of strategies, programs and policies to reduce inequities and poverty in vulnerable populations.

\section{Methodology}

A qualitative study with an exploratory descriptive design in two successive phases was made in Guadalajara, Mexico following the principles of cultural consensus theory and cultural consensus and cultural domain models. 


\section{Participants}

Informants were chosen by non-random purposive sampling, implying that the investigator chose the informants to have the possibility of examining variation and deviation forms vis-à-vis the phenomenon being studied. In this case and for the purpose of making a gender comparison, the sampling consisted of an equal number of Mexican males and females, adults, all of whom were approached on sidewalks a block away from a teaching hospital attending to those who do not have Social Security benefits and at a SEDESOL office where the elderly without Social Security go to apply for government economic aid in the amount of $\$ 1,160.00$ pesos every other month.

Seventy-six people without Social Security benefits were included. The size of the sample was based on the assumptions of the cultural consensus model for studying cultural patterns that calls for a small size due to the fact that average correlation tends to be high. This assumption indicates a minimum of 17 informants to classify $95 \%$ of the questions correctly, with an average cultural competence of 0.5 and a reliability level of 0.95 (Romney, Weller, \& Batchelder, 1986); these are sufficient elements to discern a minimum cultural consensus of 50 (García de Alba, Quintanilla, Sánchez, Morfín, \& Cruz, 2011). Participant selection was based on the following propositions: a) common truth; all informants came from a common culture; 2) local independence; informants' answers were given independently by each of them; and 3) homogeneity of element; all questions had the same level of difficulty and were extracted from a coherent domain (Chick, 2000; Romney, Weller, \& Batchelder, 1986; Weller, 2007).

During the first phase, 36 people in equal numbers of gender (18 women and 18 men) were interviewed to learn the meanings of their concept of happiness. Another 40 people (20 women and 20 men) participated in the second phase to learn their cultural dimensions. The average age of the participants was 65.35 years old, most of whom had primary school education and were married with an average of four children. The average years at work was 37. The main occupation was housewife or merchant in the case of the women and farmers in the case of the men, followed by different trades such as administrative work, decorator, farmer, helper, librarian, carpenter, driver, accountant, seamstress, maid, office manager, metalworker, janitor, mechanic, waiter, operator, policeman, English teacher, secretary, upholsterer, TV repairman and cobbler. As for their health, 54\% reported they had no disease. The rest reported some disease such as high blood pressure, diabetes, arthritis, osteoporosis, kidney failure, asthma, colitis, infarcts, low blood pressure, physical exhaustion, and back, prostate or knee problems. 


\section{Data gathering techniques}

Data was gathered with free lists (phase one) and pile sorting (phase two) techniques. Both techniques are adaptations of other techniques used in the field of participatory research (Chevalier, 2006). The time consumed in applying phase one was never longer than 5 minutes per participant while it was 10 to 15 minutes with each participant during the second phase. The free lists served to create lists and learn the lexemes of the happiness domain. The technique consisted of asking the informants for a written list of the first five words that popped into their heads with the term happiness. They were later asked to explain their answers. The results served to learn the cultural meaning of the concept of happiness and to enable the second phase of the study.

The pile sorting technique consisted of writing the name of each item selected on a card and requiring the participants to group similar terms in piles and to name and describe the meaning of each pile. They were not asked to estimate quantities nor were a certain number of piles required. The results served to learn the conceptual dimensions of happiness and the extent of the participants' cultural consensus.

\section{Data analysis}

Data from the first phase was analyzed according to the cultural domain model where the objective is to obtain from the participants the terms they use to describe some field of knowledge or cultural domain and to try to discover the meanings through the similarities and differences of said terms. It was based on three assumptions: 1) some domain terms stand out more, are better known, important or familiar than others. When people make free lists, they tend to mention them first; 2) individuals having better knowledge of the domain list more than those with less knowledge; and 3) the terms most mentioned indicate the most noteworthy elements of the topic (Chevalier, 2006). Operationally, the analysis of the free lists consisted of tabulating the words on the lists and processing them with Visual Anthropac 1.0 Freelists software. Words were ordered into two tables based on the data, one for the most outstanding (most frequent) items and the other for pertinent items (the most important for the informants).

The most outstanding items were ordered by categorizing the words, according to how frequently they were mentioned, as central, intermediate or peripheral elements. By ordering relevant lexemes, we obtained the product of each element's ranking with its average position on the lists, where 1 is the final ranking or the highest relevance (Chevalier, 2006). An analysis of pertinent items enabled us to find new points of view that were not observed in the frequency of mention organization, especially when some elements 
were placed at the beginning or end of the lists. The results obtained were interpreted by trying to search for the cultural meaning of the concept of happiness based on the definition, practices, components, attributes, expectations and necessities mentioned by informants.

The pile sort analysis during the second phase was based on the criterion of similarities between items, searching for similarity of meanings rather than the same meaning. This reduces the semantic task of searching for synonyms (Coxon, 1999). It was based on the following assumptions: 1) the use of concordance patterns among the informants to draw inferences about individual and shared competence; 2) when an informant says that the name of an item is $\mathrm{X}$, one must assume there is a likelihood (that may be calculated) that his or he statement is correct; 3) said likelihood must be close to 1 in the case of a knowledgeable informant and close to 0 in an uninformed informant; and 4) the greater the amount of informants that agree on an answer (when asked on an individual basis), the more certain that it is the correct cultural answer (Chick, 2000; Romney, Weller, \& Batchelder, 1986; Weller, 2007).

Pile sorting data was processed with Anthropac 4.9 software. The piles of elements were tabulated in a double entry matrix and the level of similarity among elements was evaluated. The values obtained became similarity proportions and were explored separately for individual and aggregated values. The aggregated value matrixes were analyzed in hierarchical conglomerates where the elements considered similar by the informants were assigned to the same cluster or conglomerate, while those considered different were assigned to different conglomerates. Different groups were defined in the cluster analysis to the extent possible depending on the data. The method used in this case was the links between groups, with the similarity measurement of chi squared for frequency values and using the average link. The extent of similarity between words was expressed with a dendogram or tree chart that served to reveal the perceptual dimensions that people used to distinguish the concept of happiness and to detect the groups of topics making up subdomains (Borgatti \& Halgin, 1999).

A non-metric multidimensional scaling model was used for the comparative exploration of similarities between clusters. This model tried to represent proximities in geometric space with few dimensions, without presupposing a linear relation between proximities and distances but rather to establish a growing monotonous relation between both. The procedure was based on changing the proximity matrix into a range matrix, obtaining the distance between the stimuli, comparing proximities with distances and obtaining disparities. The goodness of the model's fit was learned from the stress coefficient obtained, taking into account that the greater the difference 
between disparities and distances, the greater the stress level. The perfect stress value is zero while 0.025 is excellent, 0.050 good, 0.10 fair and 0.20 is poor (Kruskal, 1964).

The individual value matrixes were analyzed with a cultural model adjusted to ordinal responses. The model estimates the plausibility that a homogeneous system of knowledge dominates a culture based on the correspondence between group knowledge and individual knowledge. Factorial analyses were made for this purpose of the main components that grouped individuals in terms of their answers. The goodness of fit criterion to obtain consensus in the models implies that the first factor (F1) reached a ratio three times greater than the second factor (F2), which would mean the existence of high concordance in the individual answers. The results obtained in this analysis were presented in a table.

\section{Ethical considerations}

The current version of ethical standards of the Human Research Committee of the Declaration of Helsinki was met as well as the Regulations of the General Law on Health for Research Matters in Mexico and it was deemed risk-free research. The participants were aware of the objectives of the study and gave their oral informed consent. The Science and Ethics Committee of the Workers' Health and Safety Research Institute of the University Center for Health Sciences pertaining to the University of Guadalajara reviewed this study and approved it at the proper time.

All individuals participated voluntarily and were guaranteed confidentiality and anonymity in the treatment of their information. Any questions about the procedure, risks and benefits and any other matter related to the research and personal information were answered and they were informed that they may drop out of the study at any time. Nevertheless, all the individuals approached participated during the entire process.

\section{Results:}

\section{Cultural meanings of the concept of happiness}

The words most frequently mentioned by participants are listed in table 1 . The central terms of the happiness concept were defined as children and peace by women, and the lexemes of health, children, wellbeing and family by men.

Women mentioned: "Children brought happiness to my home; I bought them a house and gave them an education. I provided food, clothing and I would like to give them my life. I like to take them out for walks. There is not enough (money) any more, I like that they want for nothing and to help them when they need it with their problems. They help me with medicine and medical expenses, and with household expenses." Peace for them (the 
women) meant: "Having a job, a salary to get by on. To be with the family. To live healthily without thinking about tomorrow. To have something to solve problems with. To have their children nearby. The security of having something. If everyone is alright, I'm happy."

The domain of happiness for women is their family (it's everything, it is the foundation for future generations. If my family helps me, I'll be better off. If you have a closely knit family, you have everything. It is spending time with them); being content (for being alive); being happy (I feel good about myself, being where we are, seeing the beauty of this world); health (sometimes I consider myself to be a little sick; medicine, doctors); and their husband (he puts up the money at home for medicine and the light, water and phone bills. It's about sharing).

The practices of happiness for women were to live at ease, in harmony and with love (it encompasses your entire life; without it, you can do nothing. With love, you help as much as you can because we all need it.) Peace, work and being with others are attributes. The domain of happiness also showed expectations, especially of a religious nature: (God is who created us and we seek him to be happy. Being spiritually well. If I am full of God, it will be easier for me in the future), and emotional and family needs. See table 1.

Table 1. Frequency account for happiness domain of men and women.

\begin{tabular}{|c|c|c|c|c|c|}
\hline \multicolumn{2}{|c|}{ Women } & \multirow[b]{2}{*}{ Meaning } & \multirow[b]{2}{*}{ Classification } & \multicolumn{2}{|c|}{ Men } \\
\hline Elements & $\begin{array}{c}\text { Frequency of } \\
\text { mentions }\end{array}$ & & & $\begin{array}{c}\text { Frequency } \\
\text { of } \\
\text { mentions }\end{array}$ & Elements \\
\hline Children & 50 & \multirow{3}{*}{ Definition } & \multirow{3}{*}{$\begin{array}{l}\text { Central } \\
\text { elements }\end{array}$} & 55.6 & Health \\
\hline \multirow[b]{2}{*}{ Tranquility } & \multirow[b]{2}{*}{44.4} & & & 38.9 & Children \\
\hline & & & & 33.3 & $\begin{array}{l}\text { Wellbeing and } \\
\text { family }\end{array}$ \\
\hline $\begin{array}{l}\text { Family, content, } \\
\text { happy, health }\end{array}$ & 27.8 & \multirow{2}{*}{ Components } & \multirow{4}{*}{$\begin{array}{l}\text { Intermediate } \\
\text { elements }\end{array}$} & 27.8 & Content \\
\hline Spouse & 22.2 & & & 22.2 & $\begin{array}{l}\text { Love, peace, } \\
\text { money, work }\end{array}$ \\
\hline $\begin{array}{l}\text { Living at ease, } \\
\text { harmony, love }\end{array}$ & 16.7 & Practices & & 16.7 & $\begin{array}{c}\text { Wife, } \\
\text { economic } \\
\text { stability }\end{array}$ \\
\hline $\begin{array}{l}\text { Peace, work, } \\
\text { time together }\end{array}$ & 11.1 & Attributes & & 11.1 & $\begin{array}{l}\text { Lack of } \\
\text { medicine, } \\
\text { happy, gusto, } \\
\text { harmony, } \\
\text { home }\end{array}$ \\
\hline
\end{tabular}




\begin{tabular}{|c|c|c|c|c|c|}
\hline \multicolumn{2}{|c|}{ Women } & \multirow[b]{2}{*}{ Meaning } & \multirow[b]{2}{*}{ Classification } & \multicolumn{2}{|c|}{ Men } \\
\hline Elements & $\begin{array}{l}\text { Frequency of } \\
\text { mentions }\end{array}$ & & & $\begin{array}{l}\text { Frequency } \\
\text { of } \\
\text { mentions }\end{array}$ & Elements \\
\hline $\begin{array}{l}\text { Perfection, } \\
\text { perseverance, } \\
\text { paradise, } \\
\text { obedience, unity, } \\
\text { spiritually, effort, } \\
\text { God, Our Lady, } \\
\text { having no } \\
\text { regrets, faith, } \\
\text { heaven }\end{array}$ & & Expectations & & & $\begin{array}{c}\text { Helping } \\
\text { others, } \\
\text { comfort, not } \\
\text { having wants, } \\
\text { progress, } \\
\text { peace, no } \\
\text { problems, } \\
\text { Salary, living } \\
\text { at ease }\end{array}$ \\
\hline $\begin{array}{l}\text { Parents, } \\
\text { accompanied, } \\
\text { values, religion, } \\
\text { laughter, having } \\
\text { the basics, being } \\
\text { myself, loved } \\
\text { ones, } \\
\text { communication, } \\
\text { sharing, } \\
\text { economic } \\
\text { stability, having, } \\
\text { understanding, } \\
\text { making dreams } \\
\text { come true, } \\
\text { daughter-in-law, } \\
\text { home, not sick, } \\
\text { feeling good, } \\
\text { coherent, gusto }\end{array}$ & 5.6 & Necessities & $\begin{array}{l}\text { Peripheral } \\
\text { elements }\end{array}$ & 5.6 & $\begin{array}{c}\text { Great } \\
\text { grandchildren, } \\
\text { humility, } \\
\text { achieving } \\
\text { your desires, } \\
\text { emotional } \\
\text { stability, lack } \\
\text { of money, } \\
\text { honesty, } \\
\text { siblings, } \\
\text { nieces and } \\
\text { nephews, rest, } \\
\text { recreation, } \\
\text { security, } \\
\text { success, } \\
\text { training }\end{array}$ \\
\hline
\end{tabular}

Source: Direct.

Men commented: "Happiness is health; without health, other things are of no use to me. I don't want to be sick. You can't do anything without health. You are sad if you are not healthy." "Children bring happiness because they are company for whatever you need. I like to help them; they need it. Happiness is giving to my children so they have no wants. Sometime children don't have enough money to help their parents. It is sharing meals with them. They are whom I love. They are my children and they come first." "Wellbeing is having no needs; that's how you have peace. I feel good about it. I need to feel good to be able to help others." "Family is happiness, it is ideal, what the world wants and hopes for. A close-knit family is the hardest thing to achieve."

The concept of happiness for men consisted of the following lexemes: being content and love (without love there is nothing. It is better to live closely-knit. Love for my children makes me feel happy, supported); 
peace (being on good terms with family and neighbors. It is the consequence of love. It is being able to live trouble-free. It would be nice if they gave me the money); money (money and happiness go hand in hand); and work (thanks to work you will have your reward.)

Practices of happiness for men were the wife and economic stability, its attributes being the lack of medicine, being happy, gusto, harmony and home. The peripheral elements hinged around the expectations of helping others and making progress. Their needs included values, distant relatives and achievements. See table 1.

The relevant words of the domain of happiness are found in Tables 2 and 3. The analysis of relevance in women revealed that besides children and peace (central elements), it included the words: paradise (only there is everything fulfilled), laughter (it helps), being myself (not pretending, saying what's on my mind, being listened to), faith (you can do nothing without faith, you are not alive) and heaven (trying to be a better person) because they are named in first place on the lists. See table 2.

Table 2. Women highlight elements for happiness domain.

\begin{tabular}{|c|c|c|c|c|}
\hline Element & $\begin{array}{l}\text { Frequency of } \\
\text { mentions }\end{array}$ & Ranking & $\begin{array}{l}\text { Average } \\
\text { position on } \\
\text { the lists }\end{array}$ & Relevance \\
\hline Children & 50 & 1 & 2.22 & 2.22 \\
\hline Tranquility & 44.4 & 2 & 2.63 & 5.26 \\
\hline Content & 27.8 & 3 & 2 & 6 \\
\hline $\begin{array}{l}\text { Paradise, laughter, being myself, } \\
\text { faith, heaven }\end{array}$ & 5.6 & 7 & 1 & 7 \\
\hline Family, happy & 27.8 & 3 & 2.8 & 8.4 \\
\hline Health & 27.8 & 3 & 3 & 9 \\
\hline $\begin{array}{l}\text { Perfection, father, effort, economic } \\
\text { stability, having, God, coherent }\end{array}$ & 5.6 & 7 & 2 & 14 \\
\hline Living at ease & 16.7 & 5 & 3 & 15 \\
\hline Peace & 11.1 & 6 & 2.5 & 15 \\
\hline Husband & 22.2 & 4 & 4 & 16 \\
\hline Love & 16.7 & 5 & 3.33 & 16.65 \\
\hline Work & 11.1 & 6 & 3 & 18 \\
\hline Being together & 11.1 & 6 & 3.5 & 21 \\
\hline $\begin{array}{l}\text { Perseverance, unity, Our Lady, not } \\
\text { having regrets, gusto }\end{array}$ & 5.6 & 7 & 3 & 21 \\
\hline Harmony & 16.7 & 5 & 4.33 & 21.65 \\
\hline $\begin{array}{l}\text { Obedience, having the basics, loved } \\
\text { ones, communication, home, not } \\
\text { sick, feeling good }\end{array}$ & 5.6 & 7 & 4 & 28 \\
\hline
\end{tabular}




\begin{tabular}{|c|c|c|c|c|}
\hline $\begin{array}{c}\text { Parents, accompanied, values, } \\
\text { religion, spiritually, sharing, } \\
\text { understanding, making dreams } \\
\text { come true, daughter-in-law }\end{array}$ & 5.6 & 7 & 5 & 35 \\
\hline
\end{tabular}

Source: Direct.

The analysis of relevance in men revealed the meaning of happiness through health and children (central elements) accompanied by feeling happy (it is joy, it is the complement of happiness: one needs the other), a lack of money (everything is denied to us) and siblings (I want to help them because they are worse off than I am) because they are the lexemes named in first place on the lists. See table 3.

Table 3. Men highlight elements for happiness domain.

\begin{tabular}{|c|c|c|c|c|}
\hline Element & $\begin{array}{c}\text { Frequency of } \\
\text { mentions }\end{array}$ & Ranking & $\begin{array}{l}\text { Average } \\
\text { position on } \\
\text { the lists }\end{array}$ & Relevance \\
\hline Health & 55.6 & 1 & 2.1 & 2.1 \\
\hline Children & 38.9 & 2 & 3.29 & 6.58 \\
\hline Happy & 11.1 & 7 & 1 & 7 \\
\hline Family & 33.3 & 3 & 2.5 & 7.5 \\
\hline Lack of money, siblings & 5.6 & 8 & 1 & 8 \\
\hline Wellbeing & 33.3 & 3 & 3 & 9 \\
\hline Love, work & 22.2 & 5 & 2 & 10 \\
\hline Money & 22.2 & 5 & 2.5 & 12.5 \\
\hline Content & 27.8 & 4 & 4 & 16 \\
\hline Security, what you yearn for & 5.6 & 8 & 2 & 16 \\
\hline Tranquility & 22.2 & 5 & 3.5 & 17.5 \\
\hline Harmony, home & 11.1 & 7 & 2.5 & 17.5 \\
\hline Economic stability & 16.7 & 6 & 3 & 18 \\
\hline Spouse & 16.7 & 6 & 3.33 & 19.98 \\
\hline Lack of medicine & 11.1 & 7 & 3 & 21 \\
\hline $\begin{array}{c}\text { Progress, no problems, } \\
\text { humility }\end{array}$ & 5.6 & 8 & 3 & 24 \\
\hline Gusto & 11.1 & 7 & 3.5 & 24.5 \\
\hline $\begin{array}{l}\text { Salary, success, comfort, great } \\
\text { grandchildren, grandchildren, } \\
\text { emotional stability honesty }\end{array}$ & 5.6 & 8 & 4 & 32 \\
\hline Not lacking necessities, peace & 5.6 & 8 & 5 & 35 \\
\hline $\begin{array}{l}\text { Living at ease, recreation, } \\
\text { nieces and nephews, training, } \\
\text { rest, helping others, goods }\end{array}$ & 5.6 & 8 & 5 & 40 \\
\hline
\end{tabular}

Source: Direct.

The words chosen for women in the second phase of the study were: children, tranquility, family, content (or happy), health, husband, living, 
harmony, love, peace and work due to their central or intermediate frequency. Peripheral frequency included the words: paradise, heaven (trying to be a better person), faith, laughter, being myself, economic stability and feeling good, because they were the most relevant lexemes. The term "paying my debts" was also added because most of the women explained it was really important to receive government help to be able to pay their debts.

The words chosen for men in the second phase of the study were: health, children, wellbeing, family, content, love, tranquility, money, work, wife, economic stability, joy (or happy), gusto, harmony and house (home) because of their central or intermediate frequency. The following peripherally frequent words were included: money without working (that I want for nothing), siblings, security and triumphs (success) because they represented concerns for them. The word "complement" was also added because most of the men mentioned that it was important to receive government help as a complement for survival and even for not worrying about working.

\section{Cultural dimensions of the domain of happiness}

Dendograms representing the cultural dimensions of the domain of happiness are found in figures 1 and 2. Two dimensions were found in both men and women: economic stability and support.

In the happiness model for women, the economic stability dimension consisted of the need to have a job to eat and live well, wanting government help to buy medicine, helping their husband and paying debts. The support dimension consisted of two subdomains: the foundation for everything that brings happiness, and help to get along. The foundation for having happiness included children and family as all important; the husband to share love, and the desire to be content and to be myself, to be listened to and to not pretend. Help to get along included personal activities such as feeling good, feeling happy, the will to live, caring for one's health, and laughter; activities to be a better person and to live in tranquility, peace, harmony; that is to live without fighting and respectfully; and divine assistance activities through faith in God and in paradise.

In the happiness model for men, the economic stability dimension consisted of the need to have a job and money to have food and health; and the desire to have wellbeing, money without working through the triumph of getting government aid. The dimension of support included two domains: giving and receiving help and self-help. Giving and receiving mutual help is the ideal kind of support; i.e. what everyone wants and desires: a family, wife, children, love, a home and an economic complement from the government to get by and have everything one needs. Self-help incorporated 
a search for the meaning of life that harms no one, taking care of one's health, finding the gusto in living, living joyfully, feeling content and in harmony as well as living peacefully with security, carefree and no conflicts to maintain an emotional, physical and spiritual balance.

In the analysis of a non-metric multidimensional scale, the dimensions described in the cluster trees had poor goodness of fit values both for men (0.242) and for women (0.256).

Figure 1. Cultural dimensions of the happiness domain in women.

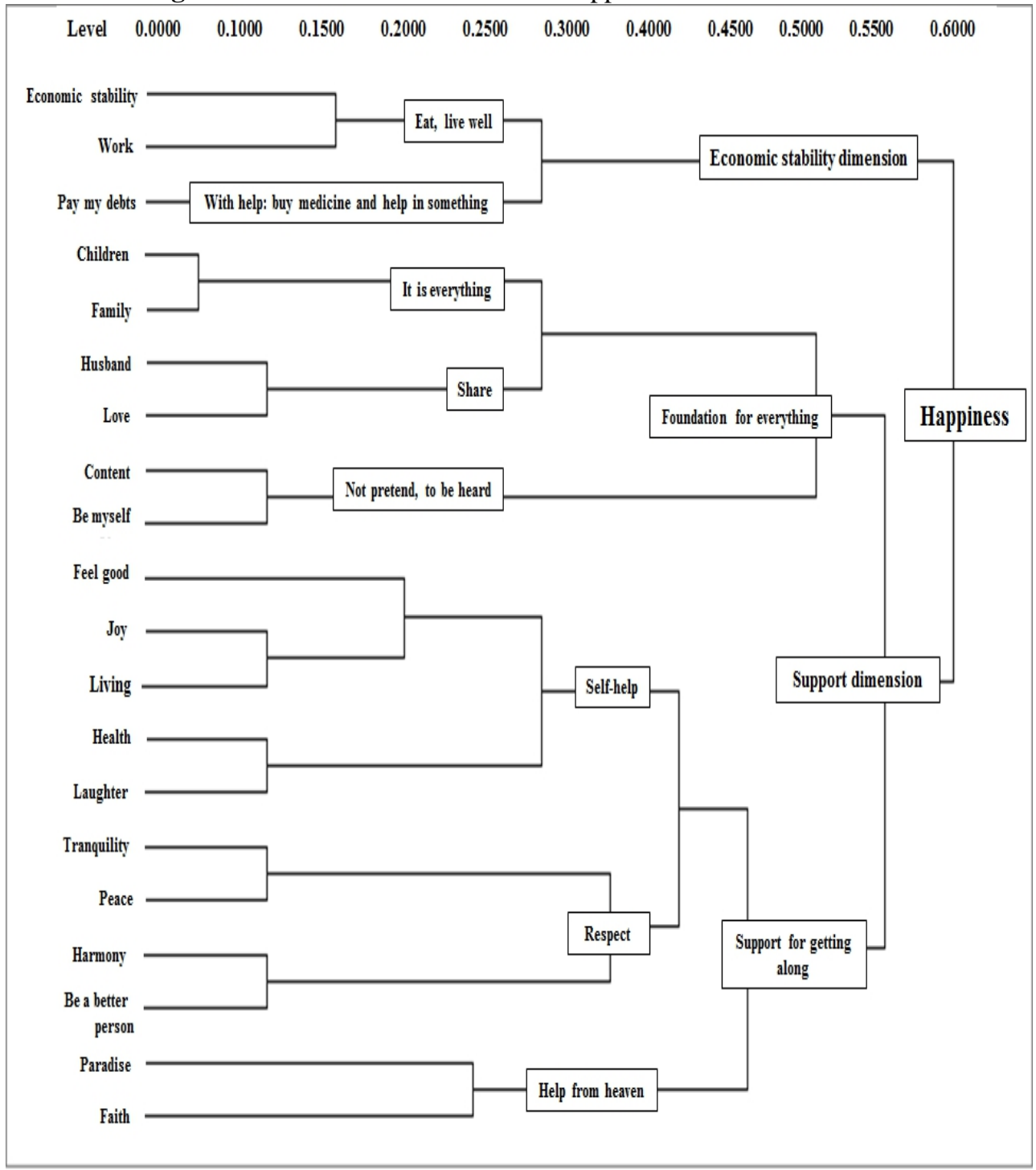

Source: Direct. 
Figure 2. Cultural dimensions of the happiness domain in men.

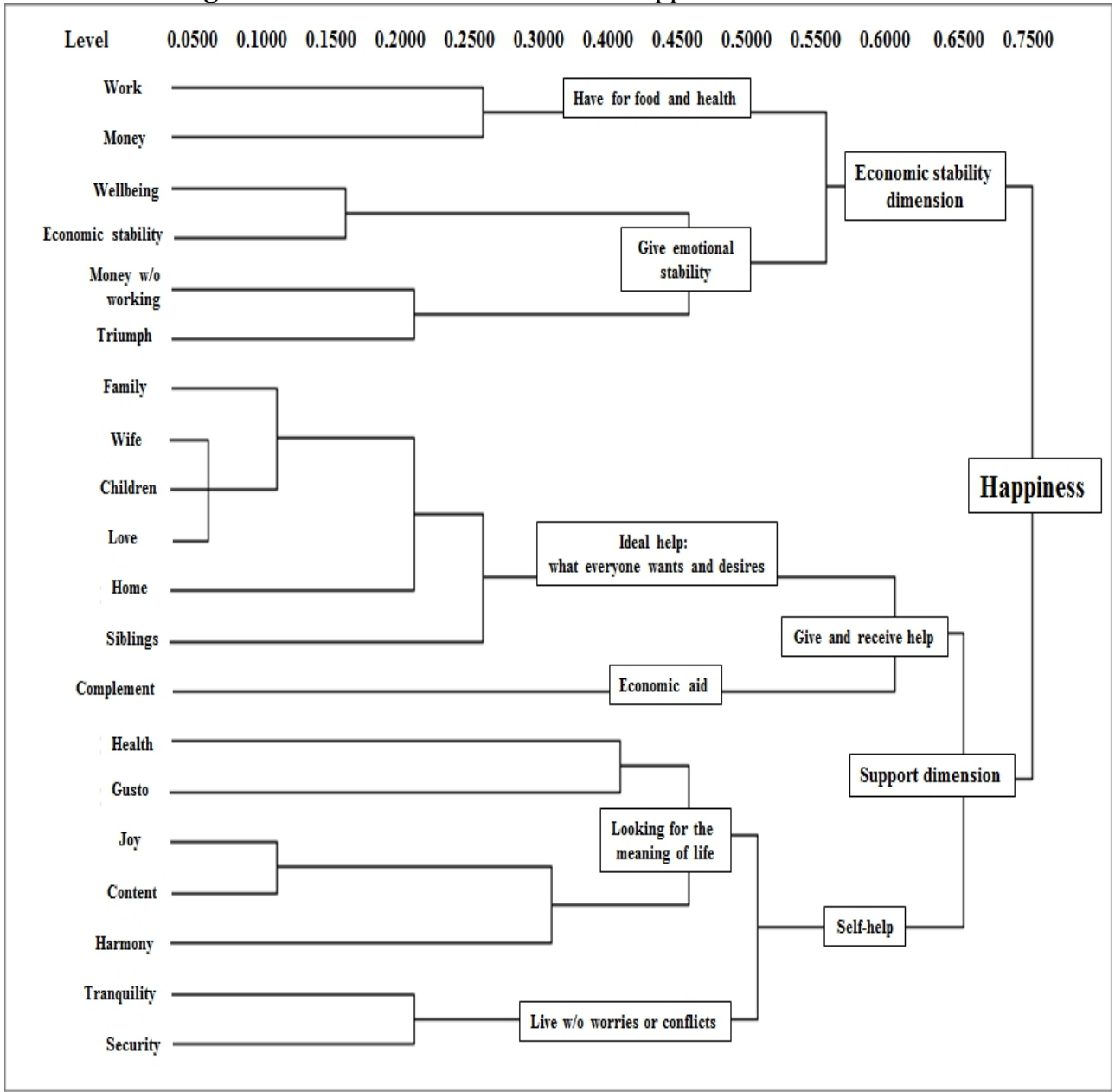

Source: Direct.

The conceptual organization of the different dimensions of happiness obtained cultural consensus in men as well as in women, with high response concordance albeit greater in women. The theoretical criterion of goodness of fit of the consensus model was met in both cases, because the ratio between F1 and F2 was greater than three. In the case of men, the model reached a ratio level of 5.924, the cumulative variance percentage for factor 1 was $79 \%$ and the mean of individual cultural competence was 0.526 with a standard deviation of 0.232 . As for the women, cultural consensus reached a level of 6.158, the cumulative variance percentage for factor 1 was $80 \%$ and the mean of individual cultural competence was 0.551 with a standard deviation of 0.304 , thus confirming a mean cultural competence level of $95 \%$ and group concordance level of $95 \%$ in both groups. See tables 4 and 5 . 
Table 4. Cultural consensus of the concept of happiness in men.

\begin{tabular}{|c|c|c|c|c|c|c|c|c|}
\hline $\begin{array}{c}\text { Male } \\
\text { nts }\end{array}$ & $\begin{array}{c}\text { Rati } \\
\text { o F1 }\end{array}$ & $\begin{array}{c}\text { Cumulati } \\
\text { ve } \\
\text { variance } \\
\%\end{array}$ & $\begin{array}{c}\text { Rati } \\
\text { o F2 }\end{array}$ & $\begin{array}{c}\text { Cumulati } \\
\text { ve } \\
\text { variance } \\
\%\end{array}$ & $\begin{array}{c}\text { Rati } \\
\text { o } \\
\text { F1:F } \\
2\end{array}$ & $\begin{array}{c}\text { Mean } \\
\text { cultural } \\
\text { competen } \\
\text { ce } * \\
\text { (Average } \\
\text { ) }\end{array}$ & $\begin{array}{c}\text { Standar } \\
\text { d } \\
\text { deviati } \\
\text { on }\end{array}$ & $\begin{array}{c}\text { Group } \\
\text { concordan } \\
\text { ce ** }\end{array}$ \\
\hline $\mathrm{n}=20$ & $\begin{array}{c}6.61 \\
3\end{array}$ & 79 & $\begin{array}{c}1.11 \\
6\end{array}$ & 92.3 & $\begin{array}{c}5.92 \\
4\end{array}$ & 0.526 & 0.232 & 0.276 \\
\hline
\end{tabular}

*Cultural competence: arithmetic group mean of the extent of individual agreement with the average answers

**Group concordance: average cultural competence means squared.

Table 5. Cultural consensus of the concept of happiness in women.

\begin{tabular}{|c|c|c|c|c|c|c|c|c|}
\hline $\begin{array}{c}\text { Female } \\
\text { Participa } \\
\text { nts }\end{array}$ & $\begin{array}{c}\text { Rati } \\
\text { o F1 }\end{array}$ & $\begin{array}{c}\text { Cumulati } \\
\text { ve } \\
\text { variance } \\
\%\end{array}$ & $\begin{array}{c}\text { Rati } \\
\text { o F2 }\end{array}$ & $\begin{array}{c}\text { Cumulati } \\
\text { ve } \\
\text { variance } \\
\%\end{array}$ & $\begin{array}{c}\text { Rati } \\
\text { o } \\
\text { F1:F } \\
2\end{array}$ & $\begin{array}{c}\text { Mean } \\
\text { cultural } \\
\text { competen } \\
\text { ce } * \\
\text { (Average } \\
\text { ) }\end{array}$ & $\begin{array}{c}\text { Standar } \\
\text { d } \\
\text { deviati } \\
\text { on }\end{array}$ & $\begin{array}{c}\text { Group } \\
\text { concordan } \\
\text { ce ** }\end{array}$ \\
\hline $\mathrm{n}=20$ & $\begin{array}{c}7.92 \\
0\end{array}$ & 80 & $\begin{array}{c}1.28 \\
6\end{array}$ & 93 & $\begin{array}{c}5.92 \\
4\end{array}$ & 0.551 & 0.304 & 0.303 \\
\hline
\end{tabular}

*Cultural competence: arithmetic group mean of the extent of individual agreement with the average answers

**Group concordance: average cultural competence means squared.

\section{Discussion}

According to the CONEVAL (2015) classification, more than a condition of vulnerability, a condition of extreme poverty was detected in the informants of this study; besides having income below the wellbeing line, they showed an educational deficit (most only had primary school studies), a lack of access to health and social security services, on repeated occasions stated their wish to obtain the support of a government pension for people without Social Security and expressed the need, among others, to purchase medicine and needed the help of their children for seeing doctors, although they recognized that at times their children could no longer help them. Extreme poverty was also found to be associated with the high average number of children of both men and women and deep-

A more comprehensive cultural meaning of happiness was found than the ones reported by other authors who wrote studies on Finland, Poland, Spain and México (Miret et al., 2014; Salazar \& Arenas, 2016), where happiness was associated only with health. In this study, children and tranquility were also an essential part of the cultural meaning of happiness as were the economic and personal dimensions making up the cultural consensus model. 
The meanings and the two large conceptual dimensions of happiness of this study agree with the proposal of Carrillo et al. (2017) of focusing the study of happiness on affective relationships, prosocial behavior and investment in others, given that the adults of our study expressed a need of love and of helping. It also agrees with the world happiness reports (Helliwell et al., 2016) about the possibility of increasing countries' happiness, given that the people in this study mentioned mutual help by parents and children and the wish to help siblings that are worse off. This does not agree with the world happiness reports in that the informants in this study did not express knowledge about sustainable development policies. We consider that this term has an ethical conception that is not part of the cultural knowledge of those in conditions of vulnerability and extreme poverty.

Meanings and the two large conceptual dimensions of happiness were found in the women in this study from a Christian religious viewpoint in search of paradise after death as mentioned by one author (Mauri, 2005). Both men and women stated their wish for a harmonic peaceful life, contrary to what Ramírez (2017) wrote about the inhabitants of the Far East countries that consider happiness to be internal harmony. The above may be explained because our study deals with people in extreme poverty for whom obtaining medicine is a total odyssey, who may not have contemplated consuming or attaining beauty due to the high cost implied therein. Furthermore, the pursuit of harmony and peace may be associated with age more than people's geographic location.

On the other hand, happiness and subjective wellbeing were not found to be equivalent as cited previously by another author (Escalante, 2016). Nor did the informants in this study associate happiness with food (Lobos et al., 2015; Pinzón, 2017; Schnettler et al., 2014). Nevertheless, there was agreement with other authors (González-Quiñones \& RestrepoChavarriaga, 2010) with regards to social support networks such as God, oneself, mother and/or siblings who shore up people's happiness, although in this case, children were the main promotors of happiness of the adults in this study, followed by spouses, siblings, grandchildren great grandchildren and a daughter-in-law.

Unlike a comparative study between Argentina and Spain, the people in this study did not state their knowledge of psychological wellbeing (Muratori et al., 2015) since they only mentioned wellbeing as peace where nothing is wanting. On the other hand, the people in this study did express ambivalence about the meanings of happiness, just as Pereira et al. found (2014), especially the men who mentioned the lack of medicine and a lack of economic stability as attributes of happiness. 
In Mexico, unlike Bhutan, Korea, Japan and Brazil, government officials do not seek to measure inhabitants' happiness nor have they thought about amending the Constitution to guarantee free access to much needed basic public health services. In this regard, the UN should pressure countries to incorporate the new economic paradigm of a happy country because otherwise, as in the case of the people in this study, most of the population will attribute happiness to merely personal and economic questions without understanding it has to do with the political willingness to help the poor and vulnerable sectors of society, as stated by the WHO in 2015. It would be unfortunate for a nation's development, as indicated by Alvarado (2016), if it continued to be impossible for the State to make anyone happy, given that the subjects of this study expressed joy when they learned they could count on economic aid from the State, albeit for a minimum amount.

\section{Conclusion}

The objective of this study was met. Cultural meanings of happiness by a group of elderly adults were analyzed, they were different for men than for women, with a common axis of love of their children. Happiness for women meant children and tranquility and for men it meant health, children, wellbeing and family. The cultural consensus of the conceptual models of men and women was analyzed and there was high concordance of individual and group answers, showing that the people in this study were aware of the importance of happiness and how to reach it. Their major limiting factor was being excluded from Social Security and not having money or government aid. Despite the high concordance in cultural consensus, the stress measurement or goodness of fit measurement of the models was poor; i.e. the informants did belong to a cultural group and the population was homogeneous with normal standard deviation. Although sample selection could be improved in future studies because despite the fact that all participants were elderly adults in a condition of poverty, some had different levels of education and marital status.

Two conceptual dimensions were observed both in men and in women. In the dimension of economic stability (having money to eat and for health care), it was found they had work in common, and regarding economic stability, men expressed a desire to transcend. In the dimension of support, the main coincidence was love of family, children, spouse, maintaining and caring for their health, being content and living joyfully, in harmony and peace. The difference observed in this support dimension was the importance given in the men's model to covering household expenses, helping siblings, receiving economic aid in order to feel at ease and secure. On the other hand, women had a less committed view that centered more on 
themselves, looking to laugh, feel good, have peace, strengthen their faith and a better person to reach paradise after they pass away.

This study contributes information about common shared knowledge in the cultural domain of happiness by estimating cultural beliefs and the extent to which individuals know about or report such beliefs. It has also succeeded in growing the amount of scientific knowledge about the happiness of this group of participants by means of an easily applied model with easy access to their concepts and beliefs.

\section{Recommendations}

The recommendation is that the State lend support urgently to the elderly by providing free health care and medicine as well as sufficient stable economic aid for both men and women over 60. It also needs to promote knowledge and experiences to women beyond their religious beliefs as well as the practice of laughter and peace among men for the purpose of all of them widening their expectations towards travelling, and having fun, leisure time and recreational activities.

\section{References:}

1. Ahmad, K., \& Pieroni, A. (2016). Folk knowledge of wild food plants among the tribal communities of Thakht-e-Sulaiman Hills, North-West Pakistan. Journal of Ethnobiology and Ethnomedicine, 12, 17. doi:10.1186/s13002-016-0090-2.

2. Alcántara-Salinas, G., Ellen, R. F., Valiñas-Coalla, L., Caballero, J., \& Argueta-Villamar, A. (2013). Alternative ways of representing Zapotec and Cuicatec folk classification of birds: a multidimensional model and its implications for culturally-informed conservation in Oaxaca, México. Journal of Ethnobiology and Ethnomedicine, 98, 1. doi:10.1186/1746-4269-9-81.

3. Alvarado, J. (2016). ¿Derecho a la felicidad? Díkaion, 25(2), 243265. doi:10.5294/dika.2016.25.2.5.

4. Álvarez, L. Y. (2012). Escala de creencias acerca de la felicidad en población adulta de la ciudad de Bucaramanga (Colombia). Investigación y Desarrollo, 20(2), 302-333.

5. Árraga, M. V., \& Sánchez, M. (2012). Validez y confiabilidad de la Escala de Felicidad de Lima en adultos mayores venezolanos. Universitas Psychologica, 11(2), 381-393.

6. Barragán, A. R. (2013). Aproximaciones científicas al estudio de la felicidad: ¿qué podemos aprender de la felicidad? Revista Intercontinental de Psicología y Educación, 15, 2, 7-24. 
7. Bilbao, M. A., Techio, E. M., \& Páez, D. (2007). Felicidad, cultura y valores personales: estado de la cuestión y síntesis meta-analítica. Psicología, 25(2), 233-276.

8. Borgatti, S. (1994). Cultural Domain Analysis. Journal of Quantitativave Anthropology, 261-278.

9. Borgatti, S. (1998). Elicitation techniques for cultural domain analysis. The Etnographer's Toolkit. Altamira Press, 3, 1-26.

10. Borgatti, S. (1999). Guía del etnógrafo. Tomo 3. Walnut Creek: Comunicado de Altamira.

11. Bourey, C., Stephenson, R., Bartel, D., \& Rubardt, M. (2012). Pile sorting innovations: Exploring gender norms, power and equity in sub-Saharan Africa. Global Public Health, 7(9), 995-1008. doi:10.1080/17441692.2012.709259.

12. Brandt, R., Mathez-Stiefel, S., Lachmuth, S., Hensen, I., \& Rist, S. (2013). Knowledge and valuation of Andean agroforestry species: the role of sex, age, and migration among members of a rural community in Bolivia. Journal of Ethnobiology and Ethnomedicine, 9, 83. doi:10.1186/1746-4269-9-83.

13. Broberger, E., Tishelman, C., von Essen, L., Doukkali, E., \& Sprangers, M. G. (2007). Spontaneous reports of most distressing concerns in patients with inoperable lung cancer: at present, in retrospect and in comparison with EORTC-QLQ-C30+LC13. Quality of Life Research: An International Journal of Quality of Life Aspects of Treatment, Care and Rehabilitation, 16(10), 1635-1645.

14. Bueno, G. (2005). El mito de la felicidad. Barcelona: Ediciones B.

15. Carrillo, S., Feijóo, M. L., Gutiérrez, A., Jara, P., \& Schellekens, M. (2017). El papel de la dimensión colectiva en el estudio de la felicidad. Revista Colombiana de Psicología, 26(1), 115-129.

16. Castillo, C. O., \& Silva Costa, M. C. (2008). Meanings regarding the use of alcohol in families of a venezuelan poor community. Revista Latino-Americana de Enfermagem (RLAE), 16(4), 535-542.

17. Chevalier, J. M. (2006). Listados libres y clasificación por montones. Sistemas de Análisis Social 1.0. 2006. Disponible en: http://wwwsas-pm.com/.

18. Chick, G. (2000). Writting culture reliably: The analysis of highconcordance codes. Etnology, 39, 365-393.

19. CEPAL. (2015). México, uno de los tres países donde creció la pobreza. Comunicado de prensa. Disponible en: http://www.cepal.org/es/comunicados/se-estanca-la-reduccion-de-lapobreza-y-la-indigencia-en-la-mayoria-de-los-paises-de.

20. CONEVAL. (2015). Medición de la pobreza en México y en las entidades federativas 2014. Ciudad de México: Comunicado de 
Prensa 005. 23 de julio de 2015. Disponible en: http://www.coneval.org.mx/Medicion/Documents/Pobreza\%202014_ CONEVAL_web.pdf

21. Coxon, A. A. (1999). Sorting data: Collection and analysis. Thousand Oaks, CA: Sage.

22. D'Andrade, R. (2003). The development of cognitive anthropology. Cambridge: University Press.

23. D'Ambrosio, U., \& Puri, R. K. (2016). Foodways in transition: food plants, diet and local perceptions of change in a Costa Rican Ngäbe community. Journal of Ethnobiology and Ethnomedicine, 123. doi:10.1186/s13002-015-0071-X.

24. Eberhart, N., Sherbourne, C., Edelen, M., Stucky, B., Sin, N., \& Lara, M. (2014). Development of a measure of asthma-specific quality of life among adults. Quality of Life Research, 23(3), 837-848.

25. Escalante, E. (2016). Nota sobre el concepto de bienestar o felicidad y los sucesos de vida: una aproximación a partir de hallazgos teóricos y empíricos. Revista Panorama, 10(19), 1-14.

26. García de Alba, J. E., Quintanilla, R., Sánchez, L. M., Morfín, T., Cruz, J. I. (2011). Consenso cultural sobre el intento de suicidio en adolescentes. Revista Colombiana de Psicología, 20, 2, 167-179. Disponible en: http://www.redalyc.org/articulo.oa?id=80421265002

27. González-Quiñones, J. C., \& Restrepo-Chavarriaga, G. (2010). The prevalence of happiness in life-cycles and regarding support networks in the Colombian population. Revista de Salud Pública, 12(2), 228238.

28. Helliwell, J. F., Layard, R., \& Sachs, J. (Eds). (2012). World Happiness Report. New York, US: Sustainable Development Solutions Network.

29. Helliwell, J. F., Layard, R., \& Sachs, J. (Eds). (2013). World Happiness Report 2013. New York, US: Sustainable Development Solutions Network.

30. Helliwell, J. F., Layard, R., \& Sachs, J. (Eds). (2015). World Happiness Report 2015. New York, US: Sustainable Development Solutions Network.

31. Helliwell, J. F., Layard, R., \& Sachs, J. (Eds). (2016). World Happiness Report. Vol 1. New York, US: Sustainable Development Solutions Network.

32. Kruskal, J. B. (1964). Nonmetric multidimensional scaling: a numerical method. Psychometrika, 2, 115-129.

33. Lind, J. D., Powell-Cope, G., Chavez, M. A., Fraser, M., \& Harrow, J. (2013). Negotiating domains of patient dignity in va spinal cord 
injury units: perspectives from interdisciplinary care teams and veterans. Annals of Anthropological Practice, 37(2), 130-148.

34. Lobos, G., Mora, M., Lapo, M., Caligaria, C., \& Schnettlerd, B. (2015). Happiness and health and food-related variables: Evidence for different age groups in Chile. Suma Psicológica, 22(2), 120-128. doi:10.1016/j.sumpsi.2015.09.002.

35. Mauri, M. (2015). Tesis básicas sobre la felicidad y la libertad. Barcelona: Universitat de Barcelona.

36. Meza, J. P., \& Fahoome, G. F. (2008). The development of an instrument for measuring healing. Annals of Family Medicine, 6(4), 355-360. doi:10.1370/afm.869.

37. Miret, M., Caballero, F. F., Chatterji, S., Olaya, B., TobiaszAdamczyk, B., Koskinen, S., \& Ayuso-Mateos, J. L. (2014). Health and happiness: cross-sectional household surveys in Finland, Poland and Spain. Bulletin of The World Health Organization, 92(10), 716725. doi:10.2471/BLT.13.129254.

38. Morrison, S. D., Sudha, S., Herrera, S., Ruiz, C., \& Thomas, E. (2016). En sus propias palabras: latina women's perspectives on enablers of hiv testing using freelisting. Health Education Journal, 75(1), 3-13.

39. ONU. (2012). Relación entre felicidad y desarrollo. Disponible en: http://www.un.org/spanish/News/story.asp?newsID=23084\#.WNxKb qK71PY.

40. Pereira, D. L., Guedes, F. J., Ferreira, H., Carvalho, J. Evangelista, L., \& Fortes, M. (2014). A dupla face da velhice: o olhar de idosos sobre o processo de envelhecimento. Enfermagem em Foco 4(1), 1518.

41. Ramírez, E. D. (2017). En México no hay derecho a la felicidad. Reporte especial. Disponible en: http://www.poblanerias.com/2017/03/en-mexico-no-hay-derecho-ala-felicidad/.

42. Romney, K., Boyd, J., Moore, C., Batchelder, W., \& Brazill, T. (1996). Culture as shared cognitive representations. Proceedings of National Academy of Sciences. 93, 4699-4705.

43. Romney, K., Weller, S., \& Batchelder, W. (1986). Culture as consensus: A theory of culture and informant accuracy. American Anthropologist, 88, 313-338.

44. Salazar, J. J., \& Arenas, L. A. (2016). Un modelo económico de felicidad y su evidencia para México. Estudios Sociales: Revista de Investigación Científica, 24(47), 1-31. 
45. SMU. (2013). Acerca de quiénes han opinado sobre la felicidad. Revista electrónica del SMU. Disponible en: www.smu.org.uy/elsmu/comisiones/reencuentro/jornadas/felicidad.

46. Sithey, G., Thow, A. M., \& Li, M. (2006). Felicidad nacional bruta y salud: lecciones desde Bhután. Boletín de la Organización Mundial de la Salud. doi: 10.2471/BLT.15.160754. Disponible en: www.smu.org.uy/elsmu/comisiones/reencuentro/jornadas/felicidad2.

47. Torres-López, T. M., Soltero-Avelar, R., \& Herrera-Pérez, J. I. (2012). Cultural dimensions concerning healthcare workers in México and Colombia having dengue. Revista de Salud Pública, 14(1), 67-80.

48. Walker, K. O., Clarke, R., Ryan, G., \& Brown, A. F. (2011). Effect of closure of a local safety-net hospital on primary care physicians' perceptions of their role in patient care. Annals of Family Medicine, 9(6), 496-503. doi:10.1370/afm.1317.

49. Weller, S., \& Romney, K. (1988). Systematic Data Collection. Newbury Park, Beverly Hills, London, New Delhi: Sage.

50. Weller, S. (2007). Cultural Consensus Theory: Applications and Frequently Asked Questions. Field Methods, 339-368. 